\title{
Does Training Learners on Language Learning Strategies Have Any Effect on Language Achievement?
}

\author{
By Nuray Okumus Ceylan ${ }^{1}$
}

\begin{abstract}
This study aims to find out whether training learners on language learning strategies has an effect on foreign language learning achievement or not. The population is Kocaeli University 2013- 2014 education year Foreign Languages School students. This study is an experimental study in which randomly chosen experimental and control classes take part, and only the experimental classes were trained on language learning strategies for the defined period of time and observed until the end of the first term on their use of the language learning strategies. At the end of the first term, language learning strategies and learner autonomy surveys were conducted again as post- tests. The significant difference between the overall averages of the first term grades of beginner/ elementary level control and experimental groups shows that training students on language learning strategies may lead to better foreign language achievement, particularly in lower levels.
\end{abstract}

Keywords: learner training; foreign language achievement

\section{Introduction}

Language learning processing strategies exist and influence second language acquisition (McLaughlin, Kinbourne, Cole, Bates \& MacWhinney, Wode, Winitz). Some of the researchers who examined and analyzed learner language have referred to universal language processing strategies, such as overgeneralization, transfer and simplification. The operation of these strategies should be considered as one cause of learner errors and the changing nature of the learners' interlanguage system (Taylor, 1975; Richards, 1975; cited in Wenden\& Rubin, 1987). Analysis of learner language has also yielded information on communication strategies learners use when faced with a gap between communicative need and inguistic repertoire (Faerch\& Kasper, 1983). These studies on universal language processing strategies and communication strategies focus on the cognitive processes involved in second language acquisition.

How learners approach the task of learning a second language is the subject of cognitive science defined as "a systematic inquiry into our thinking selves... a discipline devoted to exploring how our minds work (Hunt, 1982; 17 cited in Wenden \& Rubin, 1987). The understanding of the workings of the mind is expressed in a variety of questions (Hunt, 1982; 29 cited in Wenden \& Rubin, 1987), these questions are;

- Do we learn what we learn primarily as a result of mere repetition- or of comprehension- or of the linkage of new material to previously known material?

- By what methods do we locate, in our memories, whatever we want to remember?

- Has what is forgotten merely faded out, or been erased or merely misfiled?

- Does the human mind spontaneously come to reason along the lines of formal logic or

Associate Professor in English Language and Literature Department in Bulent Ecevit University, Turkey. 
does it, instead, have a quite different natural logic of its own?

- What do we do that enables us to see, at some point, that certain things can be grouped into a coherent category, or that a general rule can be extracted from a series of experiences?

- Do we learn to imitate grammatical speech as we grow up or are grammatical structures genetically prewired in the brain's language area?

- What are the processes we use consciously or unconsciously when solving problems both great and small and can the individual's problem solving ability be improved by training?

- What do highly creative people do that ordinary people don't do?

- What kinds of thinking go on unconsciously, as contrasted to those kinds that are conscious?

- How is our thinking affected or skewed by our sex, age, personality, and background? Cognitive science bases its assumptions on these questions. Information comes in through our sense receptors. At this time selected items of information are attended to, identified, and, then, moved into the short-term or working memory. In short-term memory a series of mental operations are applied to this information. Then, the changed or modified product is stored in long-term memory to be retrieved when it is needed. The mental operations that encoded incoming information are referred to as processes. The changes brought about by these processes are referred to as organizations of knowledge or knowledge structures. The techniques actually used to manipulate the incoming information and, later, to retrieve what has been stored are referred to as cognitive strategies.

The literature on learning strategies in second language acquisition emerged from a concern for identifying the characteristics of effective learners. Research focusing on the "good language learner" (Naiman et. Al. 1978; Rubin, 1975; cited in Wenden\& Rubin, 1987) had identified strategies reported by students or observed in the language learning situations that appear to contribute to learning. The literature showed that students do apply strategies while learning a second language and that these strategies can be described and classified.

Learners need assistance to learn autonomously and teachers play a key role in providing this (Benson, 2001; Gardner \& Miller, 1999; Sinclair, McGrath \& Lamb, 2000). "Learning training is a key for teachers to help learners autonomously including two important areas: raising learner awareness of how languages are learned and providing them with the skills they need to do it" (Logan \& Moore, 2004; p. 1). Tudor (1996; p. 37) describes learning training as "the process by which learners are helped to deepen their understanding of the nature of language learning and to acquire the knowledge and skills they need in order to pursue their learning goals in an informal and self- directed manner".

Dickinson (1988) states that there are three main components to provide a successful learner training:

- Training learners in the processes and strategies for language learning

- Raising learner awareness of how the target language operates

- Focusing on the theory of second language acquisition 
The need for learner autonomy extends beyond the foreign/ second language classroom and beyond the time learners spend acquiring another language (Wenden, 1998). Therefore, learner training activities are expected to prepare learners for lifelong learning (e.g. Westhoff, 1990; Eriksson, 1993; Dam, 1995; Shiels, 1993; Thomson, 1996). Benson (2003) states that the aim of training is to enable learners to become effective agents of change within their educational context.

Cohen (2003) states that strategy training aims to provide learners with the tools to do:

- Self- diagnose their strengths and weaknesses in language learning

- Become aware of what helps them to learn the target language most efficiently

- Develop a broad range of problem- solving skills

- Experiment with familiar and unfamiliar learning strategies

- Make decisions about how to approach a language task

- Monitor and self- evaluate their performance

- Transfer successful strategies to new learning contexts (p.1)

Many researchers have explicitly stressed the importance of learner training for learner autonomy (e.g. Holec, 1981; Huttunen, 1986; Cotterall, 1995; Dickinson, 1995; Dam 1995; Oxford, 1990; Wenden, 1991). Holec (1985) explains the aim of the training as preparing learners to direct their own learning so that they may gradually move from a state of dependence on a teacher to the greatest degree of independence or autonomy possible in a particular set of circumstances. Benson (2001; p.146) states that "there is good evidence that learner development programs can be effective in improving language learning performance. Research done on learner training indicates that training learners on language learning strategies has a positive effect on learners' language proficiency.

\section{Research on Learner Training}

Alparda (2010) investigated the effect of learner training on students' ability to benefit from Computer Assisted Language Learning (CALL) effectively. Strategy training appeared to have a positive effect on students' motivation to attend the lab lessons and engage in the lab activities. Balkır (2007) concludes that learner training and awareness building activities have resulted in a significant improvement in learners' perceptions of responsibility and a moderate increase in their motivational level. Torun (2010) revealed that teaching vocabulary learning strategies explicitly helps learners adopt more strategies, which leads to vocabulary development. The experimental group was observed to use more vocabulary learning strategies after the treatment and while there was no statistical difference between the control and the experimental groups in terms of proficiency before the treatment, the subjects in the experimental group improved their vocabulary knowledge much more than the control group. Odac1 (2006) revealed that after the listening comprehension strategy training, experimental group had a significantly higher level of listening proficiency than the control group. However, at the beginning of the study there was no significant difference between two groups. 


\section{Research Design}

This study aims to find out whether learner training may result in better language achievement or not by training foreign language learners on language learning strategies. Research questions are:

1. What sort of language learning strategies do KOUPS' students employ?

2. In the pre-test prior to the study, do the experimental groups significantly differ from control groups in terms of language learning strategies?

3. In the post-test after the study, do the experimental groups significantly differ from control groups in terms of language learning strategies?

4. Is there any statistically significant difference between the pre- and post-test scores of the control groups in terms of language learning strategies?

5. Is there any statistically significant difference between the pre- and post-test scores of the experimental groups in terms of language learning strategies?

6. Does training students on language learning strategies have an effect on foreign language achievement?

The study is conducted at Kocaeli University English Prep School. The students are attended to B (beginner/ elementary) and A (pre-intermediate/ intermediate) level classes according to the results of the placement test at the beginning of the 2013-2014 academic year. This is an quasi-experimental study in which experimental and control classes equivalent in proficiency level are chosen to take part in. The quantitative data analyzed was gathered via a questionnaire. At the beginning of the fall term, language learning strategies questionnaire was administered as pre-test. Then, the experimental classes were trained on language learning strategies for the defined period of time and observed until the end of the first term on their use of the language learning strategies. The control groups did not receive any training. At the end of the first term, language learning strategies questionnaire was administered again as post- test.

\section{Population and Sample}

In this study, the population is Kocaeli University 2013- 2014 academic year Foreign Languages School students. There are eight classes randomly chosen, four B (beginner/ elementary) level classes and four A (pre-intermediate/ intermediate) level classes that take part in the study. The level of the classes is identified by the placement test administered at the beginning of 2013- 2014 academic year. The students are assigned to the classes based on their placement test results.

The randomly chosen classes (B 4-6-15-17; A 10-11-12-13) are at the similar level, and they are the classes of the teacher- researcher (T1) and a teacher's (T2) classes who are the participants in the study. 'B' level classes have 24 hours of General English lessons weekly. Each class has two teachers, one is the teacher- researcher (T1), and the other is another teacher from the institution. The study is only conducted in the teacherresearcher's lessons, for 12 hours a week. 'A' level classes have 20 hours of General English lessons every week. Each group taking part in the study has two teachers, one is the teacher- participant (T2), and the other is another teacher from the institution. The study is only conducted in the teacher- participant's lessons, for 10 hours a week. 


\section{Strategy Training}

Strategy training was based on Oxford's strategy training model (1990) in which seven steps suggesting how to implement strategy training are identified as follows:

- Determine learners' needs and the resources available for training.

- Select the strategies to be taught.

- Consider the benefits of integrated strategy training.

- Consider motivational issues.

- Prepare the materials and activities.

- Conduct explicit strategy training.

- Evaluate and revise the strategy training.

Strategy training started after the pre-tests were conducted to experimental and control groups. The experimental groups attended training. Training included activities based on the content to be covered in the syllabus of the 2013- 2014 fall academic year and the parallel strategies that were identified to be taught. These activities were provided by the researcher in an attempt to train students in some language learning strategies and raise their awareness of cognitive and metacognitive strategies which would enable them to develop autonomy and improve their language skills. The activities in the strategy training process included materials and exercises focused on teaching reading, vocabulary, writing, listening and speaking strategies. These materials were retrieved from different books and sources and some of them were modified for training purposes based on the sample activities provided by Oxford (1990) to teach language learning strategies. The training was conducted in the first two weeks of the academic year (11-15 November, 18-22 November). During this training process, teacher-trainers did the activities prepared for the study in their classes with the students. The researcher prepared weekly plans to include strategy training into the syllabus, and along with the syllabus to be covered teacher- trainers covered strategy training, too. Then, teachertrainers helped students to transfer newly-learned strategy knowledge to the materials in their course book by reminding them of which strategy could be used with the material, how it could be used and why it should be used. Students were often informed about the rationale of the strategy training activities to raise their awareness of the strategies. Students were observed until the end of the term on their use of language learning strategies.

\section{Findings}

To gather data, Strategy Inventory for Language Learning (SILL, Oxford) pretest was conducted to identify the strategy use of the students. Likert scale of five items was used.

\subsection{What sort of language learning strategies do KOUPS' students employ?}

The results show that the control AND EXPERIMENTAL groups sometimes use the strategies to remember more effectively (part A). They reported that they sometimes use all their mental processes (part B) such as "starting conversations in English" or "writing new words several times". They sometimes compensate for missing information 
(part C) by" making guesses about what the other person can say" or "reading in English without looking up every new word". They reported that they sometimes organize and evaluate their learning (part D) by "making plans" or "finding ways for practice". They sometimes manage their emotions (part E) through "encouraging" or "rewarding themselves". They reported they sometimes learn with others (part F): they "ask for help" or "practice with other students". The results suggest that the students in control groups are aware of the language learning strategies that may help them take control over their learning process leading to better language proficiency. The fact that they sometimes use language learning strategies shows that they have weak control over their learning process. They are aware of the strategies that may provide them necessary help in their language learning process; however, they fail to use them effectively.

6.2 In the pre-test prior to the study, do the experimental groups significantly differ from control groups in terms of language learning strategies?

Table 1. Independent T-test results of Control and Experimental Groups Strategy Pre- Test

\begin{tabular}{lcccccc}
\hline & $\mathbf{N}$ & $\mathbf{X}$ & $\mathbf{S S}$ & $\mathbf{S d}$ & $\mathbf{t}$ & $\mathbf{p}$ \\
\hline Control & 82 & 1.50 & 24.7 & 148 & -.445 & .657 \\
\hline Experimental & 68 & 1.52 & 24.2 & 143 & -.446 & .656 \\
\hline$* \mathrm{p}<0.05$ & & & & & &
\end{tabular}

As the results in Table 1 show, control and experimental groups do not differ significantly in terms of strategy pre-test.

6.3 In the post-test after the study, do the experimental groups significantly differ from control groups in terms of language learning strategies?

Table 2. Independent T-test results of Control and Experimental Groups Strategy Post- Test

\begin{tabular}{lcccccc}
\hline & $\mathbf{N}$ & $\mathbf{X}$ & $\mathbf{S S}$ & $\mathbf{S d}$ & $\mathbf{t}$ & $\mathbf{p}$ \\
\hline Control & 64 & 1.56 & 24.5 & 134 & -.187 & .852 \\
\hline Experimental & 72 & 1.57 & 25.8 & 133 & -.188 & .851 \\
\hline$* \mathrm{p}<0.05$ & & & & & &
\end{tabular}

As seen in Table 2 show, control and experimental groups do not differ significantly in terms of strategy post-test.

\subsection{Is there any statistically significant difference between the pre- and post-test scores of the control groups in terms of language learning strategies?}

As shown by the data in Table 3 show, the pre-test mean score of the control group for the strategy questionnaire is $1.5(\mathrm{SD}=24.7)$ and the post-test mean score of the control group is 1.2 ( $\mathrm{SD}=68.6)$. It was found out that the difference between the mean scores is statistically significant $\left(\mathrm{t}_{(81)}=3.4 ; \mathrm{p}<0.05\right)$. The control group performed significantly better in the pre-test than in the post-test. 
Table 3. Paired Samples T- test Results of the Control Group Pre- and Post- Strategy Questionnaires

\begin{tabular}{lcccccc}
\hline & N & X & SD & df & t & p \\
\hline Pre-test & 82 & 1.5 & 24.7 & \multirow{2}{*}{81} & \multirow{2}{*}{3.4} & .001 \\
Post-test & 82 & 1.2 & 68.6 & & & \\
\hline
\end{tabular}

$*_{\mathrm{p}}<0.05$

\subsection{Is there any statistically significant difference between the pre- and post-test scores of the experimental groups in terms of language learning strategies?}

As the results described in Table 4 show, the pre-test mean score of the experimental group for the strategy questionnaire is $1.2(\mathrm{SD}=61.6)$ and the post-test mean score of the experimental group is 1.3 ( $\mathrm{SD}=57.1)$. It was found out that the difference between the mean scores is statistically significant $\left(\mathrm{t}_{(81)}=-2.3 ; \mathrm{p}<0.05\right)$. The experimental group performed significantly better in the post test than in the pre-test.

Table 4. Paired Samples T- test Results of the Experimental Group Pre- and Post- Strategy Questionnaires

\begin{tabular}{ccccccc}
\hline & $\mathbf{N}$ & $\mathbf{X}$ & $\mathbf{S D}$ & $\mathbf{d f}$ & $\mathbf{t}$ & $\mathbf{p}$ \\
\hline Pre-test & 72 & 1.2 & 61.6 & \multirow{2}{*}{81} & -2.3 & .021 \\
Post-test & 72 & 1.3 & 57.1 & & & \\
\hline
\end{tabular}

$*_{\mathrm{p}}<0.05$

\subsection{Does training students on language learning strategies have an effect on foreign language achievement?}

Table 5. The Overall Averages of Control and Experimental Groups

\begin{tabular}{cccccccr}
\hline \multicolumn{3}{c}{ Beginner/ Elementary } & \multicolumn{4}{c}{ Pre-intermediate/ Intermediate } \\
\hline Control 1 & 64 & Experimental 1 & 79.6 & Control 1 & 72.7 & Experimental 1 & 76.4 \\
\hline Control 2 & 67.1 & Experimental 2 & 77.1 & Control 2 & 80.9 & Experimental 2 & 83.5 \\
\hline
\end{tabular}

There is not a significant difference between the overall averages of the first term grades of pre-intermediate/ intermediate level control and experimental groups. The significant difference between the overall averages of the first term grades of beginner/ elementary level control and experimental groups shows that training students on language learning strategies may lead to better foreign language achievement, particularly in lower levels.

\section{Conclusion}

The data shows that the students employ direct (cognitive) and indirect (metacognitive) strategies which shows that they emphasize both learning and using the target language. The data shows a significant difference only between the strategy pre and post test of the experimental groups, especially in beginner level. There is not a significant difference only between the strategy pre and post test of the control groups. Balkir's (2007) study supports the results that it showed learner training and awareness building activities resulted in a significant improvement in learners' perceptions of responsibility The fact that the students tended to use language learning strategies more 
frequently or more strategies is a sign of learner development in the level of autonomy. As Holec (1985) states students set off from a state of dependence on a teacher to independence; this is a continuum and a long process when all the circumstances of their education context considered.

As Tudor (1996; 34) states, "the knowledge and personal qualities that learner involvement requires cannot be taken for granted and need to be developed over time". As (Logan\& Moore, 2004; p. 1) states we cannot assume that learners know how to learn, we should train them for better language learning performance. Provided that strategy training is included in the curriculum and students are taught cognitive and metacognitive language learning strategies regularly and systematically, it is likely to promote autonomous learning. Griffiths (2003) supports this idea by stating that if strategies are taught to students in order that they can solve the problems they come across, they can be encouraged to take responsibility for their own learning.

The significant difference between the overall averages of the first term grades of beginner/ elementary level control and experimental groups shows that training students on language learning strategies may lead to better foreign language achievement, particularly in lower levels. We might conclude that the more strategies the students employ or more frequently the higher language learning achievement level they have. The data shows that training language learners on language learning strategies at beginner/ elementary level is effective which means that the students benefitted from the strategy training mostly at the beginning of their language learning process. It is a fact that the students face a huge variety of input and difficulties mostly at the beginning of their language learning process where the target language is generally totally different from their mother tongue. This study shows that strategy training learners help them in this challenging process; thus, we should include strategy training in our curriculum to ease the difficulty level. Learner training aims to help learners consider the factors that affect their learning and discover the learning strategies that suit them best and which are appropriate to their learning context, so that they may become more effective learners and take on more responsibility for their own learning (Sinclair, 2000: 66). As the literature suggests, training learners on language learning strategies may result in better language achievement (Ablard\& Lipschultz, 1998, Corno\& Mandinach, 1983, Zimmerman\& Risenberg, 1997, Zhang\& Li, 2004, Dafei, 2007). This study also suggests and supports that training learners in learning English as a second or foreign language process may help improve their English language achievement.

\section{References}

Ablard, K. E., Lipschultz, R. E.(1998). Self-regulated learning in high-achieving students: Relations to advanced reasoning, achievement goals, and gender. Journal of Educational Psychology, Vol 90(1), Mar 1998, 94-101.

Algan, N. (2006). The language learning strategies used by the university preparatory students and the instructors ' awareness of their students` use of these strategies. Published MA Thesis, Marmara University, English Language Teaching Department.

Alparda, Ç. (2010). The role of learner training in the effectiveness of CALL. Published MA Thesis, Bilkent University, English Language Teaching Department. 
Balkır, N. (2007). An investigation into the effects of learner training and awareness building activities on learners' perceptions of responsibility in learning English. Published MA Thesis, Çanakkale Onsekiz Mart University, English Language Teaching Department.

Bandura, A. (1989). Social cognitive theory. In R. Vasta (Ed.), Annals of child development. Vol. 6. Six theories of child development (pp. 1-60). Greenwich, CT: JAI Press.

Bares, D. (1976) From Communication to Curriculum. Harmondsworth: Penguin.

Bekleyen, N. (2005). İngilizce Öğretmen Adaylarının Dil Öğrenme Stratejileri Kullanımı. Retrieved on $28^{\text {th }}$ July 2013, from http://www.academia.edu/487258/ingilizce_ogretmen_adaylarinin dil_ogrenme_stratejileri_kullanimi

Benson, P. (2001). Teaching and researching autonomy in language learning. London: Longman

Benson, P. (2003). Learner autonomy in the classroom. In D. Nunan (Ed.), Practical English language teaching (pp. 289-308). New York, NY: McGraw Hill.

Candy, P. (1991). Self- direction for lifelong learning: A comprehensive guide to theory and practice. San Francisco: Jossey- Bass Publishers.

Chan, V., Spratt, M., \& Humphreys, G. (2002). Autonomous language learning: Hong Kong tertiary students" attitudes and behaviours. Evaluation and Research in Education, 16 (1), 1 - 18.

Çoban, Z. (2002). Attitudes Towards Learner Autonomy in Gazi University and Yuldz Teknik University. Paper presented at the International INGED Conference on Interchanges and Exchanges: Current Trends in ELT, Metu, Ankara, Turkey.

Cohen, A. D. (2003). The learner's side of foreign language learning: Where do styles, strategies, and tasks meet? IRAL, 41(4), 279-291.

Cohen, A. D., (1992). The role of learner strategy training in ELT methodology. In A. Wongsothorn et. al. (eds.), Explorations and innovations in ELT methodology. Bangkok, Thailand: Chulalongkorn University Language Institute, 1992.

Corno, L. \& Mandinach, E. B. (1983). The role of cognitive engagement in classroom learning and motivation. Educational Psychologist, 18, 88-108.

Cotterall, S. (1995). Developing a course strategy for learner autonomy. English Language Teaching Journal, 49(3), 219-227.

Cotterall, S. (2000). Promoting learner autonomy through the curriculum: Principles for designing language courses. ELT Journal, 54 (2), 109-117.

Dafei, D. (2007). An exploration of the relationship between learner autonomy and English Proficiency. Professional Teaching Articles (2007).

Dakin, J. (1973). The language laboratory and modern language teaching.

Dam, L. (1990). Learner Autonomy in Practice: An experiment in learning and teaching. Autonomy in Language Learning. I. Gathercole (Ed). Great Britain. Centre for Information on Language Teaching and Research.

Dam, L. (1995). Learner Autonomy 3: From theory to classroom practice, Dublin, Authentik.

Dickinson, L. (1987). Self-instruction in language learning. Cambridge: Cambridge University Press.

Dickinson, L. (1992). Talking shop: Aspects of autonomous learning, An interview with Leslie Dickinson. ELT Journal, 47 (1), 330-341.

Dickinson, L. (1995). Autonomy and motivation: A literature review. System, 23(2), 165-174.

Doyal, L. \& Gough, I. (1991). A Theory of Human Need, Macmillan.

Ehrman, M.E. \& Oxford, R.L., 1991. Affective Survey. Unpublished manuscript.

Ellis, R. (1994). The study of second language acquisition. Oxford: Oxford University Press.

Faerch, M. \& Kasper, G. (1983). Strategies in Interlanguage Communication. London: Longman.

Gremmo, M.J. and Riley, P. (1995). Autonomy, self-direction and self access in language teaching and learning: The history of an idea. System, 23, (2), 151-164.

Griffiths, C. (2003). Patterns of language learning strategy use, System, 31, 367- 383.

Holec, H. (1979) Autonomy and Foreign Language Learning. Strasbourg, France: Council for Cultural Cooperation.

Holec, H. (1980). Autonomy and foreign language learning. Nancy: Centre de Recherches et d'Applications Pedagogiques en Langues. Council of Europe.

Holec, H. (1981). Autonomy and foreign language learning. Oxford: Pergamon.

Holec, H. (1985). On autonomy: some elementary concepts. In P. Riley (Ed.), Discourse and learning (pp. 17390). London: Longman. 
Holec, H. (1987). The learner as manager: managing learning or managing to learn? In A. Wenden \& J. Rubin (Eds.). Learner strategies in language learning (pp.145- 56). Cambridge: Prentice-Hall.

Holec, H. (Ed.). (1988). Autonomy and self-directed learning: Present fields of application.Strasbourg: Council of Europe.

Hounsell, D. (1997). Understanding Teacbing and Teaching for Understanding in The Experience of Learning: Implications for Teaching and Studying in Higher Education, Ed. Marton, F.,

Hounsell, D., \& Entwistle, N.,, pp. 238-257, Edinburgh: Scottish Academic Press.

Huttunen, I. (1986). Learning to learn languages: investigating learner strategies and learner autonomy. Report on Workshop 2B. Council for Cultural Cooperation. Council of Europe. Strasbourg.

Karabiyık, A. (2008). The Relationship Between Culture of Learning and Turkish University Preparatory Students' Readiness for Learner Autonomy. MA Thesis; The Graduate School of Education of Bilkent University.

Kohonen, V. , (1991). Foreign language learning as learner education: facilitating self- direction in language learning. Council of Europe Symposim. Ruschlikong. Switzerland.

Kennedy, J.(2002). Learner Autonomy: A Realistic Proposition for Turkish Students. In M. Monty and M. Godfrey (Eds.). Global Problems and Local Solutions. Proceedings of ELT Conference (pp.118-122). İstanbul: Işık University.

Lee, I. (1997) Supporting greater autonomy in language learning. ELT Journal, Vol. 52/4, October, 1998. Retrieved on $28^{\text {th }}$ July 2013, from http://eltj.oxfordjournals.org/content/52/4/282.abstract

Little, D. (1995). Leaning as dialogue: The dependence of learner autonomy on teacher autonomy. System, 23(2), 175-181.

Little, D. (1996a). Freedom to learn and compulsion to interact: promoting learner autonomy through the use of information systems and information technologies. In R. Pemberton, S.L.

Little, D. (1996b). The politics of learner autonomy. Learning Learning (newsletter of the JALT Learner Development N-SIG) 2(4), 7-10. Paper presented at the Fifth Nordic Workshop on Developing Autonomous Learning, 24-27 August 1995, Copenhagen, Denmark.

Little, D. (2002) Constructing a theory of learner autonomy: some steps along the way. Retrieved on $28^{\text {th }}$ July 2013, from http://archive.ecml.at/mtp2/Elp_tt/Results/DM_layout/Reference\%20Materials /English/David\%20Little\%20Constructing\%20a\%20Theory\%20of\%20Learner\%20Autonomy.pdf

Littlewood, W. (1996). Autonomy: An anatomy and a framework. System, 24/ 4/ 427- 435.

Logan, S., \& Moore, N., (2003). Implementing learner training from a teacher's perspective. Proceedings of the Independent Learning Conference 2003. Published 20 September 2003.

Naiman, N., Fröhlich, M. Stern, H. H. \& Todesco, A. (1978). The Good Language Learner. Toronto, Ontario: Ontario Institute for Studies in Education.

Norton, B., \& Toohey, K. (2002). Identity and language learning. In R. B. Kaplan (Ed.), The Oxford handbook of applied linguistics (pp. 115-116). Oxford: Oxford University Press.

Nunan, D. (1996). Towards autonomous learning: Some theoretical, empirical and practical issues, Taking control: Autonomy in language learning, R, Pemberton, et al. Hong Kong University Press.

Odac1, T. (2006). The Effect of explicit listening comprehension strategy training on listening comprehension strategy use and listening proficiency level. Published Master's, thesis, Anadolu University, English Language Teaching Department.

O’Malley, M. J., \& Chamot, U. A. (1990). Learning strategies in second language learning. Cambridge: Cambridge University Press.

Oxford, L. R. (1990). Language learning strategies. Boston: Heinle \& Heinle.

Oxford, R. \& Ehrman, M. (1990). Adult language learning styles and strategies in an intensive training setting. The Modern Language Journal, 74(3). Retrieved on $6^{\text {th }}$ November 2002, from

Pearson, P.D., and J.A. Doyle. (1987). "Explicit Comprehension Instruction: A Review of the Research and a New Conceptualization of Instruction." Elementary School Journal 18: 151-166.

Reinders, H. (2000). Do it yourself? A learners' perspective on learner autonomy and self-access language learning.Unpublished master's thesis, Groningen University.

Reinders, H. (2007). Learner and Teacher Autonomy, Concepts, Realities and Responses. Amsterdam, John Benjamins.

Sinclair, B. (2000) Learner autonomy: The next phase? In B. Sinclair, I. McGrath and T. Lamb (eds.) Learner autonomy, teacher autonomy: Future directions. London: Longman. 
Sinclair, B., I. McGrath and T. Lamb (eds.) (2000). Learner autonomy, teacher autonomy: Future directions. London: Longman.

Shiels, J. (1993). The workshop within the context of the Council of Europe's modern languages program. In I. Huttunen Learning to learn languages: investigating learner strategies and learner autonomy. Report on Workshop 2B. Council for Cultural Cooperation. Council of Europe. Strasbourg.

Tholin, J. (2007). Learner Autonomy, Self-Directed Learning and Assessment: Lessons from Swedish Experience. Independence 40 (Spring 2007).

Torun, Y. U. (2010). The effects of strategy training on learners' vocabulary development. Unpublished Master's, thesis, Gaziantep University, English Language Teaching Department.

Tudor, I. (1993). Teacher roles in the learner-centered classroom. ELT Journal, 47(1), 23- 24.

Tudor, I. (1996). Learner- Centredness as Language Education. Cambridge University Press: UK.

Wenden, A. \& Rubin, J. (1987). Learner strategies in language learning. Cambridge: Prentice-Hall.

Wenden, A. (1991). Learner strategies in learner autonomy. UK: Prentice Hall.

Westhoff, G. (1990). Learner strategies in information processing. In M. Biddle \& P. Malmberg (eds) Learning to learn: investigating learner strategies and learner autonomy: report on workshop $2 \mathrm{a}$.

Language Learning for European Citizenship. Council for Cultural Cooperation. Uppsala: University of Uppsala, Sweden.

Zhang, L.X. \& Li X.X. (2004). A comparative study on learner autonomy between Chinese students and west European students. Foreign Language World, 4, 15- 23. 